\section{Om å møte krenkede kvinner}

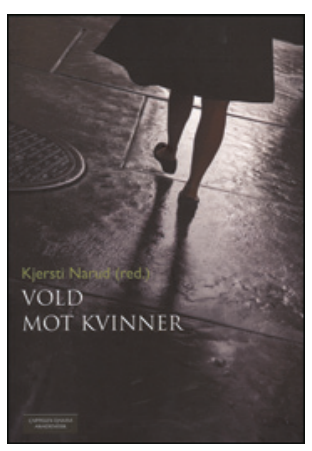

Kjersti Narud, red

Vold mot kvinner

368 s, ill. Oslo: Cappelen Damm Akademisk,

2014. Pris NOK 499

ISBN 978-82-02-41877-9

Den foreliggende boken tar mål av seg å være en lærebok om det sosiokulturelle fenomenet Vold mot kvinner slik det fremstår i dagens Norge. Boken er ment for studenter i fag hvor spørsmål og oppgaver knyttet til dette emnet kan tenkes å ha relevans, slik som helse- og sosialfag, pedagogikk, barnevern, sosiologi, demografi, psykologi, jus, politivesen og sjelesorg - og eventuelt flere.

At kvinner i stort omfang utsettes for et helt spektrum av voldelige overgrep og krenkelser er nå godt dokumentert både internasjonalt og i Norge. Fra å være usynlig og sosialt fortiet, eller i en viss forstand akseptert, er krenkelser av kvinners integritet i sine ulike uttrykksformer blitt et anerkjent forskningsfelt, som ikke er ett enkelt fags klare domene. Det igjen skyldes fenomenets sammensatte natur og varierende kontekst, slik at det må belyses fra mange perspektiver for å bli forståelig og - forhåpentlig - håndterbart med tanke på samfunnets respons.

Boken omfatter 21 bidrag fra medisin og helsefag, samfunnsfag, psykologi, jus og teologi. De føyer seg sammen til en fremstilling av særpreget og utfordringene som er knyttet til at kvinner krenkes i stor skala. Gjennom disse kvinnenes krenkelseserfaring berøres deres barn, slik at vold mot kvinner må ses i et transgenerasjonelt perspektiv.

Bidragene omhandler skift i synet på overgrep mot kvinner, juridiske aspekter med henblikk på sivil- og strafferett og juridisk bistand, og refleksjoner rundt fortellinger som muligens er autentiske. Jeg går i så fall ut fra at personene det gjelder, har samtykket. Forfatterne omtaler psykisk vold og «stalking» (systematisk personforfølgelse), den spesielle utsattheten som kjennetegner eldre kvinner, de kulturelle føringene som knytter ære til overgrep, barns erfaringer når deres mor mishandles, menns ulike måter å være voldelige på og innvirkningen av krenkelser på en kvinnes sosiale liv og yrkesaktivitet. I flere kapitler belyser forfatterne hvordan fagpersoner kan bistå, hjelpe, verne og støtte krenkede kvinner som oppsøker dem, eller som flykter til krisesentra.

Det korte stikkordregisteret skulle vært mer omfattende. Spekteret av faglige drøftinger har ført til gjentakelser som burde ha vært redigert. Disse innvendingene er imidlertid underordnet. Problematisk er det derimot at volden stort sett omtales i substantivform, som om den ikke var noe som gjøres mot noen, og noe som erfares av noen.

Språket, forsknings- og avstandspreget, virker mot formålet, som trolig er å belyse levd liv. Enkelte fagstemmer er direkte forstyrrende - de holder liv i uholdbare dikotomier, som «psyken» og «kroppen», og omtaler disse som om de var autonome aktører uten sammenheng med den erfarende, krenkede personen. En slik forståelse synes jeg er uforenlig med at boken skal opplyse fremtidige fagpersoner om hvordan man best møter krenkede kvinner.

\section{Ikke bare for dansere}

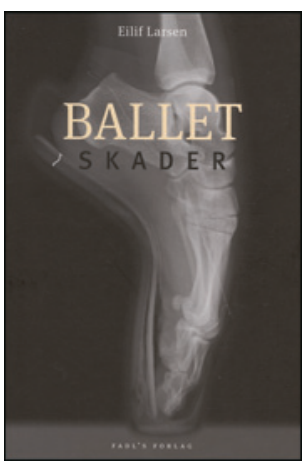

Eilif Larsen

Balletskader

260 s, ill. København: FADL's Forlag, 2014

Pris DKK 380

ISBN 978-87-7749-709-4

Tittelen er misvisende. Ballettskader er noe de aller færreste leger kommer i kontakt med, og man kunne derfor tro at boken bare var for de få utvalgte. Det er den ikke. Tvert imot kan dette være en oppslagsbok som de fleste leger og viderekomne studenter ville ha nytte av, da den enkelt og oversiktlig gjennomgår et vidt spekter av (idretts-)skader med tilhørende terapi - kanskje med hovedvekten på underekstremitetene.

Boken begynner riktignok med en oversikt over de belastninger som dansere utsettes for. Ballett er langt fra noen «frøkensport», men et beinhardt yrke på linje med toppidrett, og med belastninger som toppidrettsfolk utsettes for, noe undertegnede har fått erfare etter ti år som bedriftslege for Nasjonalballetten. Innledningen følges av et kapittel om bevegelsesapparatets oppbygning, med de forskjellige vevstypenes kjemiske sammensetning, deres belastningsgrenser og mulige insuffisiensårsaker.

Hoveddelen er kapitlet om generelle skader og forebygging av disse, fra hodet til tærne. Kapitlene om hver kroppsregion innledes med en normalanatomisk gjennomgang, ledsaget av illustrasjoner fra kjente plansjeverk og egne fargefotografier og røntgenbilder, hvorpå de enkelte skadetilstandene beskrives med forslag til terapi.

Boken avsluttes med kapitler om epi- og apofyseskader hos barn/ unge, i tillegg til hvilke undersøkelsesmetoder som står til rådighet for terapeuten. Den har faste permer, et register og en tilstrekkelig litteraturliste.

Men det er også grunn til kritikk, og den gjelder den unødige bruken av enkelte «ballettspesifikke» ord som plié, relevé, demipointe etc. for å fremheve hva som kan forårsake den enkelte skadetype. En mer generell forklaring, ev. som fotnote, kunne ha bidratt til å gjøre denne utmerkede boken mer generell og lettere tilgjengelig for praktiserende leger som ikke ser så mange dansere, men som i større grad møter et flertall av de beskrevne kasus i sin praksishverdag, slik det sies på omslagets bakside. Det danske språket er lett og flytende.

Forfatteren er dansk ortoped og har i mange år vært lege for Den Kongelige Ballet i København og konsulent for Ballettzentrum Hamburg. Jeg kan tilføye at også Nasjonalballetten ved Den Norske Opera \& Ballett har konsultert ham og ofte nytt godt av hans kunnskaper innenfor det idrettslige spesialområdet som ballett er.

Boken må ikke oppfattes som «spesiallitteratur» for de få, men som et lett tilgjengelig oppslagsverk for den praktiserende lege.

Per Holck

Professor emeritus, Anatomisk avdeling

Institutt for medisinske basalfag

Universitetet i Oslo 